\title{
In vitro assessment of the combination of cylindrospermopsin and the organophosphate chlorpyrifos on the human neuroblastoma SH-SY5Y cell line
}

\author{
M.G. Hinojosa ${ }^{\mathrm{a}}$, A.I. Prieto ${ }^{\mathrm{a}}$, D. Gutiérrez-Praena ${ }^{\mathrm{a}, *}$, F.J. Moreno ${ }^{\mathrm{b}}$, A.M. Cameán ${ }^{\mathrm{a}}$, A. Jos ${ }^{\mathrm{a}}$ \\ a Área de Toxicología, Facultad de Farmacia, Universidad de Sevilla, C/Profesor García González 2, 41012, Sevilla, Spain \\ b Área de Biología Celular, Facultad de Biología, Universidad de Sevilla, Avda. Reina Mercedes s/n, 41012, Sevilla, Spain
}

\section{A R T I C L E I N F O}

\section{Keywords:}

Cylindrospermopsin

Chlorpyrifos

SH-SY5Y cells

Chemicals combination

Pollutants

\begin{abstract}
A B S T R A C T
Cylindrospermopsin (CYN) is a cyanotoxicant which occurrence is increasing due to climate change. Cylindrospermopsin is able to exert damage in the organism at several levels, among them, in the nervous system. Moreover, it is important to take into account that it is not usually present isolated in nature, but in combination with some other pollutants, being the case of the pesticide chlorpyrifos (CPF). Thus, the aim of the present work was to assess the effects of the interaction of CYN in combination with CPF in the human neuroblastoma cell line SH-SY5Y by evaluating cytotoxicity and mechanistic endpoints. The mixtures $0.25+21$, $0.5+42,1+84 \mu \mathrm{g} / \mathrm{mL}$ of CYN + CPF based on cytotoxicity results, were evaluated, and the isobologram method detected an antagonistic effect after 24 and $48 \mathrm{~h}$ of exposure. Moreover, although no alterations of reactive oxygen species were detected, a significant decrease of glutathione levels was observed after exposure to both, CPF alone and the combination, at all the concentrations and times of exposure assayed. In addition, CYN + CPF caused a marked decrease in the acetylcholinesterase activity, providing similar values to CPF alone. However, these effects were less severe than expected. All these findings, together with the morphological study results, point out that it is important to take into account the interaction of CYN with other pollutants. Further research is required to contribute to the risk assessment of CYN and other contaminants considering more realistic exposure scenarios.
\end{abstract}

\section{Introduction}

Cyanobacterial blooms are a global environmental concern due to their increased occurrence in terrestrial, marine and freshwater ecosystems, caused by climate change and human influence. Among their detrimental effects, they produce unpleasant organoleptic properties where they proliferate (Manning and Nobles, 2017). However, the main hazard is their capacity to produce cyanotoxins, toxic secondary metabolites that threaten water safety and aquatic life (Brooks et al., 2017; Buratti et al., 2017). There are different exposure routes to them, standing out the oral one as one of the most common and dangerous. Nonetheless, other relevant routes such as dermal contact or inhalation are worth to be mentioned as well (Buratti et al., 2017).

Cylindrospermopsin (CYN) is one of the most common aquatic cyanotoxicants as a consequence of the increasing occurrence of Cylindrospermopsis raciborskii blooms, the most relevant producer species (Antunes et al., 2015). However, other cyanobacterial species such as Chrysosporum ovalisporum, Aphanizomenon flos-aquae, Anabaena bergii, or Raphidiopsis curvata are able to produce this compound (Manning and Nobles, 2017). Cylindrospermopsin consists of an alkaloid with a tricyclic guanidine linked to a hydroxymethyl uracil group (Ohtani et al., 1992). The main episode of human intoxication by CYN occurred in the outbreak of 1979 in Palm Island (Australia) when 146 people were hospitalized in a local clinic with malaise, vomits, anorexia and hepatomegaly after drinking from a water supply containing CYNproducing C. raciborskii (Bourke et al., 1983; Griffiths and Saker, 2003). However, despite intoxication by drinking contaminated water, it is also feasible to be exposed by ingestion of contaminated food. In fact, the bioaccumulation of these cyanotoxicants by plants irrigated with contaminated water (Testai et al., 2016) or in exposed aquatic organisms has been demonstrated, enhancing the risk of human intoxication by the food chain (Cordeiro-Araújo et al., 2017; Gutiérrez-Praena et al., 2013; Machado et al., 2017).

Although its target organ is the liver, CYN has widely demonstrated

\footnotetext{
* Corresponding author.

E-mail address: dgpraena@us.es (D. Gutiérrez-Praena).
} 
its capacity to damage other organs, including the nervous system (Guzmán-Guillén et al., 2015; Falconer, 1999; Hawkins et al., 1985; Humpage et al., 2005; Terao et al., 1994). Its main mechanism of action is the irreversible inhibition of protein and glutathione (GSH) synthesis (Froscio et al., 2003). Moreover, CYN has demonstrated its ability to increase reactive oxygen species (ROS) production, linked to apoptosis and DNA damage (Guzmán-Guillén et al., 2013; Puerto et al., 2011), and progenotoxic effects in several cell lines (Puerto et al., 2018; Žegura et al., 2011). In addition, several studies have shown the capacity of CYN to cause neuronal damage in vitro (Hinojosa et al., 2019; Takser et al., 2016) and in vivo (Da Silva et al., 2018; Guzmán-Guillén et al., 2015), by inducing changes in the acetylcholinesterase activity (AChE) and oxidative stress (Hinojosa et al., 2019).

Furthermore, the pollution of water by pesticides and their metabolites has been of great concern due to the increasing number of pesticides used in agricultural practices and detected in water, as well as to their persistence, mobility, and toxicity (Carvalho, 2012). Among all types of pesticides, organophosphates (OP) are about $38 \%$ of the global pesticides used, due to their high effectiveness against target pests and relatively low toxicity to non-target organisms (Koly and Khan, 2018). One of the most common OP used in agriculture and residential pest is chlorpyrifos (CPF) [O,O-diethyl 0-(3, 5, 6- trichloro-2pyridinol) phosphorothionate] (Mehta et al., 2009). This OP has been detected in many samples from all over the world (Koly and Khan, 2018).

The cases of human intoxication with CPF are numerous, including symptoms of headache, dizziness, nausea, sweating, salivation, muscle twitching, unconsciousness, convulsion, and death (Eaton et al., 2008). The main mechanism of action for CPF is the inhibition of the acetylcholinesterase activity, which leads to accumulation of acetylcholine in the synaptic space, causing an excessive stimulation of postsynaptic neuronal receptors and consequent signs of toxicity (Al-Badrany and Mohammad, 2007; Mehta et al., 2009; Zheng et al., 2000). Moreover, $\mathrm{CPF}$ induces changes on macromolecule synthesis (DNA, RNA, proteins), on neurotransmitter receptors, and in signal transduction pathways, neuronal differentiation, and neurochemical effects. Furthermore, it is also capable of producing oxidative stress by lipid peroxidation and increasing ROS (Uchendu et al., 2012).

Recently, the European Food Safety Authority has established the need of studying the toxicity of the mixtures of cyanotoxins and other chemicals, as some OP pesticides were reported to potentiate the anatoxin-induced toxicity, for instance (Cook et al., 1988; Testai et al., 2016). In this sense, due to the possible coexistence of CYN and CPF in water or their bioaccumulation in aquatic organisms or crops, the aim of the present work aimed to study, for the first time, the potential interaction and effects of the combination of CYN and the pesticide CPF in the human neuroblastoma cell line SH-SY5Y, including cytotoxicity, oxidative stress, AChE inhibition, and morphological changes.

\section{Materials \& methods}

\subsection{Supplies and chemicals}

Cylindrospermopsin (purity $>95 \%$ by HPLC) was purchased from Enzo Life Sciences. Nutrient Mixture F-12 Ham and CPF were purchased from Sigma-Aldrich (Madrid, Spain). Minimum essential medium (MEM), fetal bovine serum (FBS) and cell culture reagents were obtained from Gibco (Biomol, Sevilla, Spain).

The Bradford reagent was purchased from Sigma-Aldrich (Madrid, Spain). The supplier of MTS (3-(4,5- dimethylthiazol-2-yl)-5-(3-carboxymethoxyphenyl)-2-(4- sulphophenyl)-2H-tetrazolium salt) Cell Titer $96^{\circledR}$ AQueous One Solution Cell Proliferation Assay was Promega (Biotech Iberica, Madrid, Spain).

\subsection{Model system}

SH-SY5Y cells, derived from a human neuroblastoma, were obtained from the American Type Culture Collection (CRL-2266). These cells were maintained in a MEM and F-12 (1:1) medium supplemented with $10 \%$ FBS, $1 \%$ L-glutamine $200 \mathrm{mM}, 1 \%$ sodium pyruvate, $1 \%$ non-essential amino acids, and $1 \%$ penicillin/streptomycin solution, in an atmosphere containing $5 \% \mathrm{CO}_{2}$ at $95 \%$ relative humidity at $37{ }^{\circ} \mathrm{C}\left(\mathrm{CO}_{2}\right.$ incubator, NuAire ${ }^{\circledR}$, Spain). Cells were grown $80 \%$ confluent in $75-\mathrm{cm}^{2}$ plastic flasks and harvested twice a week with $0.25 \%$ trypsin-EDTA $(1 \times)$. The quantification of the cells was performed in a Neubauer chamber. SH-SY5Y cells were plated at density of $1 \cdot 10^{5}$ cells $/ \mathrm{mL}$ to perform all the experiments.

\subsection{Toxins test solutions}

Stock solution of $1 \mathrm{mg} / \mathrm{mL}$ CYN was prepared in sterilized milliQ water, and maintained at $-20{ }^{\circ} \mathrm{C}$ until its use. Stock solution of $50 \mathrm{mg} /$ $\mathrm{mL} \mathrm{CPF}$ was prepared in absolute ethanol and maintained at $-20{ }^{\circ} \mathrm{C}$ until its use.

\subsection{Cytotoxicity assays}

SH-SY5Y cells were seeded for basal toxicity tests in 96-well tissueculture plates and, after being incubated at $37^{\circ} \mathrm{C}$ for $24 \mathrm{~h}$, the exposure took place. From the CYN-stock solution, serial dilutions in medium without serum were prepared $(0-1 \mu \mathrm{g} / \mathrm{mL} \mathrm{CYN})$ based on previous studies (Hinojosa et al., 2019). From the stock solution of CPF, serial dilutions in medium without serum were prepared $(0-200 \mu \mathrm{g} / \mathrm{mL} \mathrm{CPF})$. These concentrations were selected based on previous studies (Amani et al., 2016; Fu et al., 2019). Non-treated cells were used as negative control. A solvent control was also evaluated to ensure its innocuous role (data not shown). After replacing the medium, the addition of the exposure solutions to the plates and incubation for 24 and $48 \mathrm{~h}$ at $37{ }^{\circ} \mathrm{C}$ took place. The endpoints assayed were protein content (PC) and tetrazolium salt reduction (MTS). All the assays were performed by triplicate. All the endpoints assayed are well described in Hinojosa et al. (2019).

\subsection{Assessment of the effect of CYN-CPF combination by the isobolograms} method

Concentrations used to evaluate the toxic potential of the combination CYN-CPF were chosen based on the cytotoxicity results of CYN and CPF previously obtained (Hinojosa et al., 2019). The highest exposure concentrations for the combination studies were those obtained as the mean effective concentration $\left(\mathrm{EC}_{50}\right)$ of the most sensitive endpoint, in this case, the MTS assay at $24 \mathrm{~h}$, along with the fractions $\mathrm{EC}_{50}$ / 2 and $\mathrm{EC}_{50} / 4$. Thus, SH-SY5Y cells were exposed for 24 and $48 \mathrm{~h}$ to binary pure pollutant combinations: $\mathrm{EC}_{50} \mathrm{CYN}+\mathrm{EC}_{50} \mathrm{CPF}, \mathrm{EC}_{50} / 2$ $\mathrm{CYN}+\mathrm{EC}_{50} / 2 \mathrm{CPF}$ and $\mathrm{EC}_{50} / 4 \mathrm{CYN}+\mathrm{EC}_{50} / 4 \mathrm{CPF}$.

The isobologram method was used according to Tatay et al. (2014) to determine the type of interaction occurring when CYN and CPF are combined. This method consists of plotting the concentration-effects curves for each compound and their combinations in multiple diluted concentrations using the median-effect equation. The combination index (CI) quantifies the synergism $(\mathrm{CI}<1)$, the additivity $(\mathrm{CI}=1)$, or the antagonism $(\mathrm{CI}>1$ ) of the combinations. The CalcuSyn software calculates these CI values automatically (Biosoft, Cambridge, UK).

\subsection{Oxidative stress assays}

\subsubsection{Reactive oxygen species (ROS) generation}

The ROS production was assessed in 96-well plates using the dichlorofluorescein (DCF) assay, previously optimized by Medrano-Padial et al. (2019). Fluorescence was measured at $535 \mathrm{~nm}$ (emission) and 
$485 \mathrm{~nm}$ (excitation) after incubation for 4, 8, 12 and $24 \mathrm{~h}$.

\subsubsection{Glutathione (GSH) content}

The GSH content was measured according to Maisanaba et al. (2018). Cells were exposed and incubated for 4, 8, 12 or $24 \mathrm{~h}$. Buthionine sulfoximine (BSO) $1 \mu \mathrm{M}$ was used as positive control. Fluorescence was measured $460 \mathrm{~nm}$ (emission) and $380 \mathrm{~nm}$ (excitation).

\subsection{Acetylcholinesterase (AChE) activity determination}

Acetylcholinesterase activity was measured following the method of Ellman et al. (1961) with modifications (Santillo and Liu, 2015). Viable SH-SY5Y cells were exposed and incubated at $37^{\circ} \mathrm{C}$ for $24 \mathrm{~h}$. A solution of parathion $50 \mathrm{nM}$ was used as a positive control. Then, the medium was discarded and replaced by $200 \mu \mathrm{L}$ of a reaction mixture containing $0.5 \mathrm{mM}$ 5,5-dithio-bis-(2-nitrobenzoic acid) and $100 \mu \mathrm{M}$ acetyltiocholine per well. The resulting product of the reaction, 5-thio-2-nitrobenzoate, was measured at $410 \mathrm{~nm}$ every $90 \mathrm{~s}$ up to $1 \mathrm{~h}$.

\subsection{Morphology}

The concentrations used for the morphological study were the ones obtained in the cytotoxicity assays, being the $\mathrm{EC}_{50}$ values those obtained after $24 \mathrm{~h}$ of exposure. These values were chosen as the highest concentrations of exposure along with the fractions $\mathrm{EC}_{50} / 2$ and $\mathrm{EC}_{50} / 4$. SH-SY5Y cells were exposed for $24 \mathrm{~h}$. The procedures for the contrast, light and electron microscopies were described by Hinojosa et al. (2019).

\subsection{Calculations and statistical analysis}

Data for the cytotoxicity assays, oxidative stress biomarkers and AChE were presented as mean \pm standard deviation (SD) to control. Analysis of variance (ANOVA) followed by Dunnett's multiple comparison was carried out to perform the statistical analysis, using GraphPad InStat software (GraphPad Software Inc., La Jolla, USA). Differences were considered significant from $\mathrm{P}<0.05$. $\mathrm{EC}_{50}$ values were the result of the linear regression in the concentration-response curves.

\section{Results}

\subsection{Cytotoxicity assays}

A concentration-dependent decrease in the viability was observed in the SH-SY5Y cells after being exposed to $0-200 \mu \mathrm{g} / \mathrm{mL}$ CPF for 24 and $48 \mathrm{~h}$ (Fig. 1). The $\mathrm{EC}_{50}$ values obtained were $83.98 \pm 2.74 \mu \mathrm{g} / \mathrm{mL}$ and $85.31 \pm 7.67 \mu \mathrm{g} / \mathrm{mL}$ after $24 \mathrm{~h}$ of exposure for the MTS assay and the PC assay, respectively. In the case of the cells exposed to CPF for $48 \mathrm{~h}$, the $\mathrm{EC}_{50}$ values were $69.78 \pm 6.02 \mu \mathrm{g} / \mathrm{mL}$ and $>200 \mu \mathrm{g} / \mathrm{mL}$ for the MTS and PC assays, respectively. Thus, the MTS assay demonstrated to be the most sensitive biomarker.

\subsection{Assessment of the effect of CYN-CPF combination by the isobolograms method}

Using the $\mathrm{EC}_{50}$ value previously indicated in Hinojosa et al. (2019), the exposure concentrations of CYN were $0.25,0.5$ and $1 \mu \mathrm{g} / \mathrm{mL}$, and 21,42 and $84 \mu \mathrm{g} / \mathrm{mL}$ of $\mathrm{CPF}$, being both combined in a proportion of 1:84 for 24 or $48 \mathrm{~h}$ (Fig. 2). The experiments performed with the combination presented a CI $>1$ in the case of the cells exposed for $24 \mathrm{~h}$, confirming an antagonistic response (Fig. 3A). However, in those cells exposed for $48 \mathrm{~h}$, the response obtained was mainly synergic at low concentrations $(\mathrm{CI}<1)$ and antagonistic at higher ones $(\mathrm{CI}>1)$ (Fig. 3B).

\subsection{Oxidative stress assays}

The exposure to 21,42 or $84 \mu \mathrm{g} / \mathrm{mL}$ CPF led to no significant changes in the ROS levels compared to the control group in SH-SY5Y cells after any of the times of exposure (4, 8, 12 or 24 h) (Fig. 4A). However, it caused a significant decrease of the GSH levels after all the times of exposure to the three concentrations assayed (Fig. 4B).

Similarly, the combination of CYN and CPF (1:84) caused a reduction of the GSH levels in all the concentrations and times of exposure assayed (Fig. 4D), despite the ROS levels were not altered compared to the control group (Fig. 4C).

\subsection{Acetylcholinesterase activity}

All the concentrations of CPF $(21,42$ and $84 \mu \mathrm{g} / \mathrm{mL}$ ) reduced the AChE activity in SH-SY5Y cells. Concerning the combination, all the concentrations assayed induced a reduction of the AChE activity (Fig. 5).

\subsection{Morphology study}

Unexposed SH-SY5Y cells observed under phase-contrast microscopy showed a star-shape morphology with neurites contacting adjacent cells. The presence of mitotic processes evidenced the active proliferation of these cells (Fig. 6A). The light microscope revealed clear euchromatic nuclei with obvious nucleoli (Fig. 6B). Under electronic microscope, cells showed a big number of mitochondria in the cytoplasm, which also presented vacuole with a dense matrix (Fig. 6C).

\subsubsection{Microscope observations of cells exposed to CPF}

Cells exposed to 42.5 and $84 \mu \mathrm{g} / \mathrm{mL}$ CPF presented cell death signs under phase-contrast and light microcopies. Cytoplasmic projections diminished with a low proliferation rate. The lowest concentration caused a vacuolization of the cytoplasm (Fig. 6D and E). Ultrastructurally, mitochondrial organelles increased their size due to the entrance of water. In addition, an alteration of the pattern of the mitochondrial crests was observed. These cellular processes drove to the presence of heterophagosomes and condensation of the chromatin, a clear sign of apoptosis (Fig. 6F).

3.5.2. Microscope observations of cells exposed to the combination $C Y N+C P F$

Concerning the combination, intense vacuolization of the cytoplasm, cellular cycle detention, loss of cytoplasmic projections, and cell death were observed at the three concentrations assayed (Fig. 6G and $\mathrm{H})$. Under transmission electronic microscopy, small lipid droplets associated with mitochondrial organelles were observed. Moreover, at the highest dose assayed $(1 \mu \mathrm{g} / \mathrm{mL}$ CYN $+84 \mu \mathrm{g} / \mathrm{mL} \mathrm{CPF})$, rough endoplasmic reticulum (RER) cisternae appeared dilated with dense content, and an intense presence of heterophagosomes was observed (Fig. 6I).

\section{Discussion}

The interactive effects of chemicals and natural stressors have been reviewed (Holmstrup et al., 2010; Laskowski et al., 2010). Synergistic interactions were reported in more than $50 \%$ of the available studies of interactions between chemicals with abiotic stressors. The coexistence of multiple cyanotoxins or with some other active compounds has been described (Al-Sammak et al., 2014; Chen et al., 2017; Martínez-Ruiz and Martínez-Jerónimo, 2016; Pathmalal, 2019; Tatters et al., 2017). However, although pesticides are candidates to appear together with these substances, literature regarding this subject is almost non-existent (Asselman et al., 2014; Daam et al., 2011; Moe et al., 2012). In this sense, EFSA has highlighted the importance of addressing the concomitant exposure of other chemicals, such as pesticides, along with 
A

\section{CPF 24h}

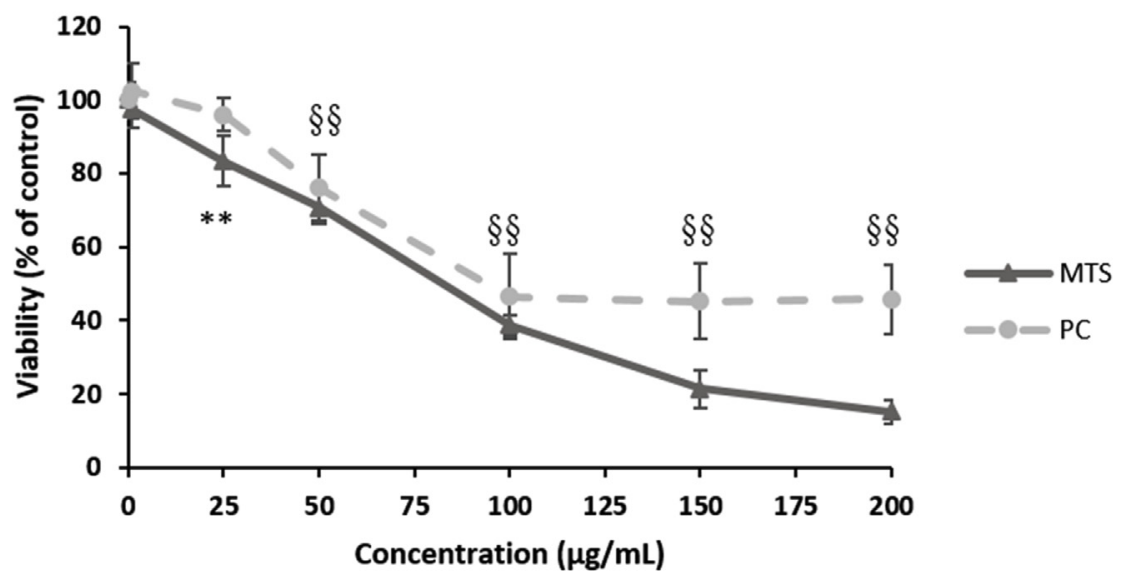

B

\section{CPF 48h}

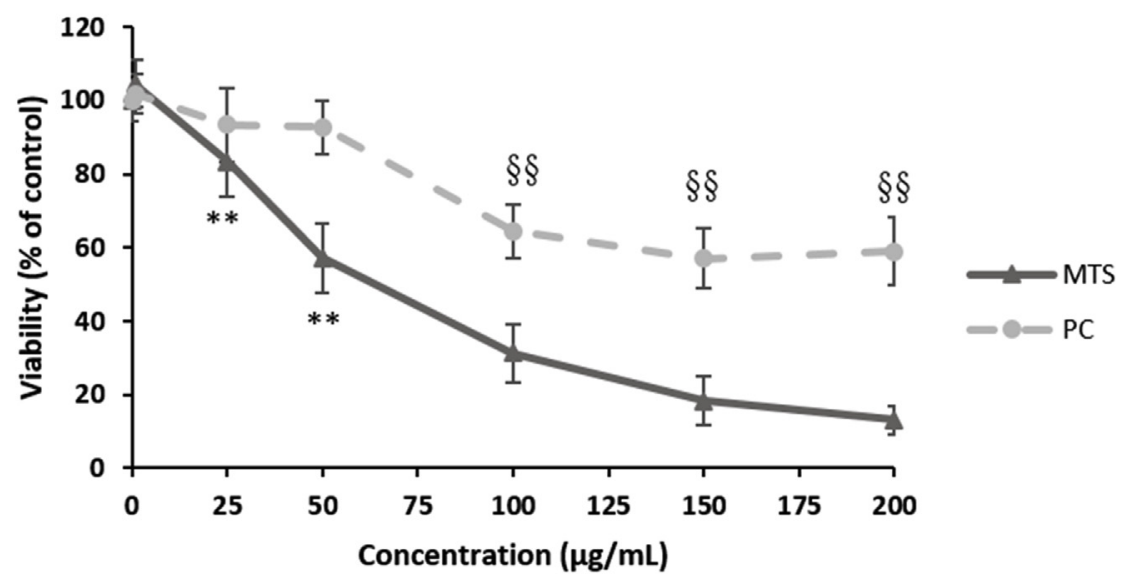

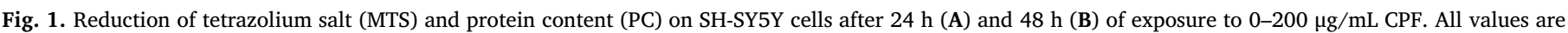

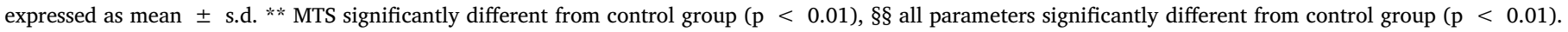

cyanotoxins in order to have information on mixture toxicity and on the environmental factors affecting toxicity of a bloom (Testai et al., 2016).

The present work focused on the potential effects induced by the combination of the CYN and the organophosphate CPF in the neuronal SH-SY5Y cell line. To address this research, a cytotoxicity study of CYN and $\mathrm{CPF}$ in the cell model was required to establish the $\mathrm{EC}_{50}$ values of the test items to be applied in the combination study. In the case of $\mathrm{CYN}$, the $\mathrm{EC}_{50}$ value of $1 \mu \mathrm{g} / \mathrm{mL} \mathrm{CYN}$ was taken from a previous work, where SH-SY5Y cells were exposed to $0-10 \mu \mathrm{g} / \mathrm{mL}$ CYN for 24 and $48 \mathrm{~h}$ (Hinojosa et al., 2019). Regarding CPF our study confirms its damaging properties in neuronal cells, showing a time- and concentration-dependent cytotoxicity. In agreement with our results, Park et al. (2013) demonstrated that CPF induced cytotoxic effects in a concentrationdependent manner in SH-SY5Y cells exposed to 0-70 $\mu \mathrm{M}$ CPF, establishing an $\mathrm{EC}_{50}$ value of $\sim 32 \mu \mathrm{g} / \mathrm{mL} \mathrm{CPF}$ after $24 \mathrm{~h}$ of exposure. Similarly, Raszewski et al. (2015) also found a time- and concentrationdependent cytotoxic behavior of CPF in SH-SY5Y cells exposed during 24,48 , and $72 \mathrm{~h}$ to $0-175 \mu \mathrm{g} / \mathrm{mL} \mathrm{CPF}$, obtaining an $\mathrm{EC}_{50}$ value for $24 \mathrm{~h}$ of $\sim 100 \mu \mathrm{g} / \mathrm{mL} \mathrm{CPF}$.

The potential mechanisms by which CPF induces its neurotoxic effects are oxidative stress and acetylcholinesterase inhibition, among others (Park et al., 2013, 2015). In our study, CPF did not show any alteration of ROS levels at any of the concentrations assayed. However,
GSH levels presented a concentration-dependent decrease, which could indicate that GSH is scavenging ROS. In this sense, Park et al. (2015) and Xu et al. (2017) found an increment in ROS levels when SH-SY5Y cells were exposed to CPF. However, they did not evaluate the GSH levels, which could give an idea about the antioxidant activity of the neuroblastoma cell line. On the other hand, Giordano et al. (2007) evaluated GSH levels of SH-SY5Y cells exposed to CPF. The authors did not find alterations in the tripeptide levels, although they observed and increment in oxidized GSH levels, which indicated that an antioxidant response was taking place, suggesting that cytotoxicity may be mediated by oxidative stress. In addition, Park et al. (2013, 2015) suggested that CPF-oxidative stress induction was related to AChE inhibition, together with its usual mechanism of action. In agreement with this, $\mathrm{CPF}$ induced a clear inhibition of the AChE activity at all the concentrations assayed in this case. Other authors have also pointed out that a depletion of GSH levels is linked to mitochondrial dysfunction, which could lead to apoptotic processes (De Oliveira et al., 2016; Park et al., 2013). This is in concordance with our morphological findings, where the highest concentrations of CPF induced mitochondrial alterations, leading to cell death by apoptosis. This process is related to the activation of caspase- 9 and -3 and an increment of cytosolic cytochrome c, as Park et al. (2015) reported for SH-SY5Y cells exposed to CPF. Considering this, Raszewski et al. (2015) proposed that CPF 

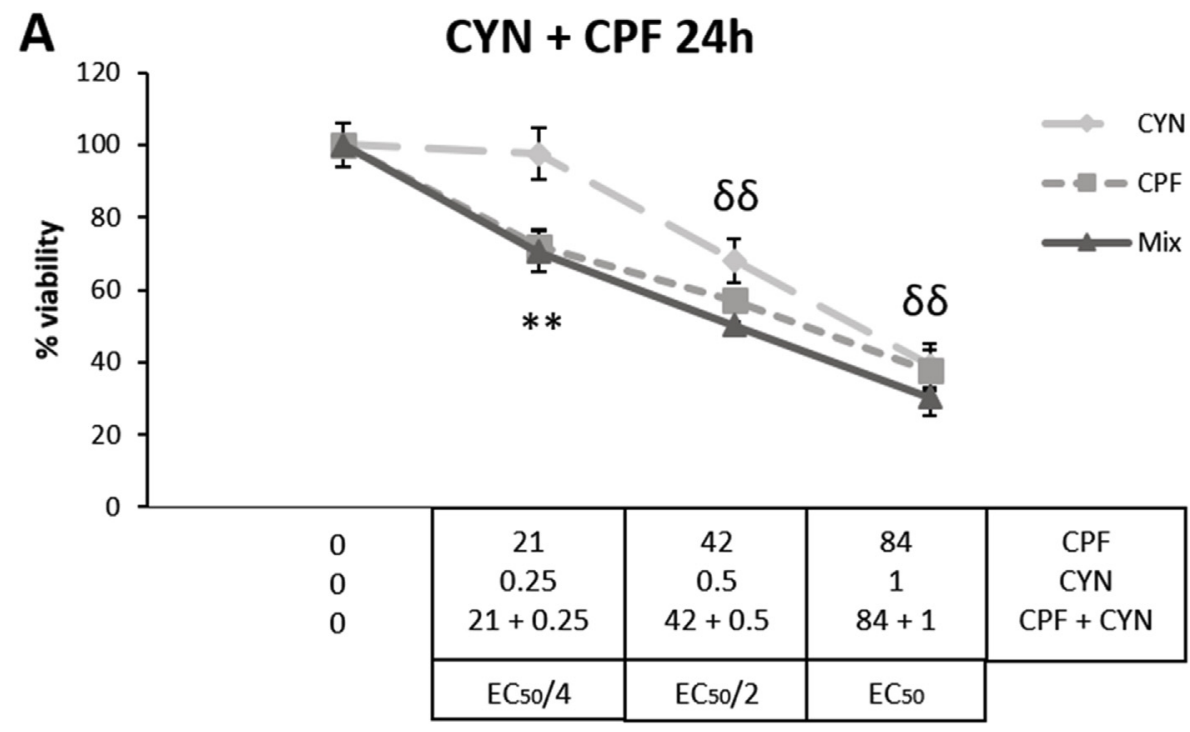

Concentration $(\mu \mathrm{g} / \mathrm{mL})$

B CYN + CPF 48h

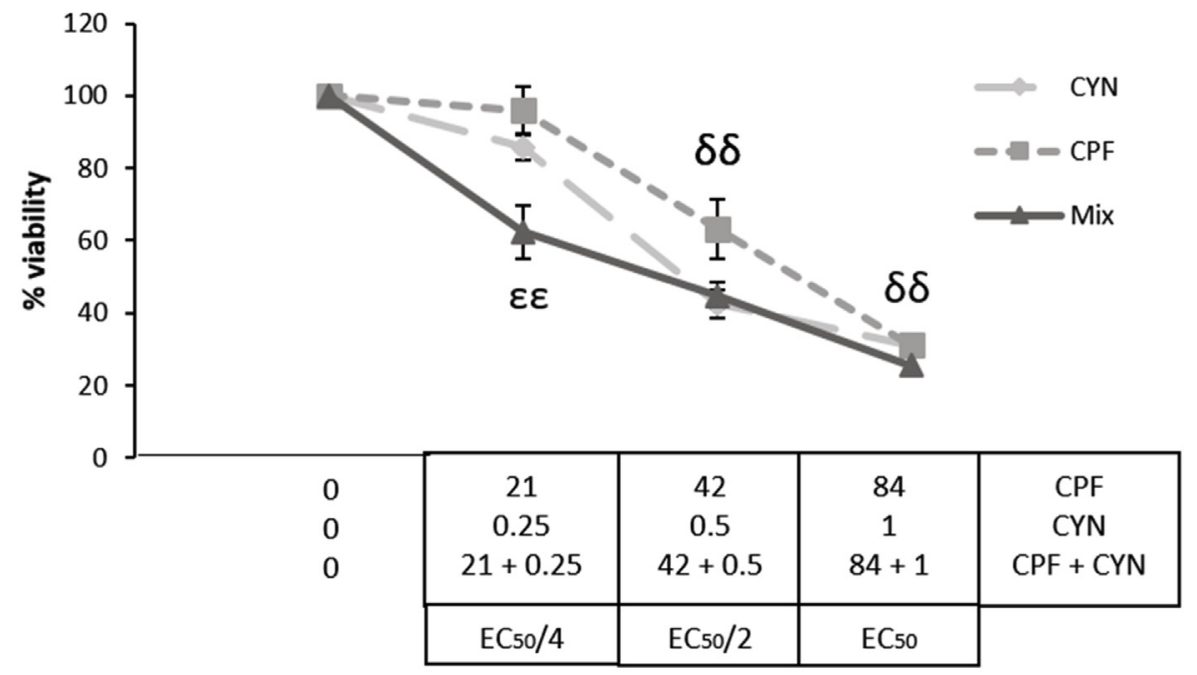

Concentration $(\mu \mathrm{g} / \mathrm{mL})$

Fig. 2. Reduction of tetrazolium salt (MTS) on SH-SY5Y cells after $24 \mathrm{~h}$ (A) and $48 \mathrm{~h}$ (B) of exposure to different concentrations of CYN + CPF combinations at a ratio of $\mathrm{EC}_{50} \mathrm{CYN} / \mathrm{EC}_{50} \mathrm{CPF}(1: 84)$. All values are expressed as mean \pm s.d. ** significantly different from control group (p < 0.01) for CPF and the combination, $\varepsilon \varepsilon$ significantly different from control group $(\mathrm{p}<0.01$ ) for CYN and the combination, and $\delta \delta$ significantly different from control group (p $<0.01$ ) for CYN, CPF and the combination.

induces neurotoxicity through apoptotic mechanisms.

Once the toxic effects of CYN (Hinojosa et al., 2019) and CPF alone on the neuronal SH-SY5Y cell line were elucidated, the behavior of their combination on the same cell line was evaluated. Our results showed that the combination was more cytotoxic than both toxicants alone after 24 and $48 \mathrm{~h}$. However, in order to establish the type of interaction between both compounds, the isobologram method was used. Thus, after $24 \mathrm{~h}$ of exposure, an antagonistic response was observed. This pattern changed after $48 \mathrm{~h}$, showing a synergistic response at low concentrations, and turning to an antagonistic response at higher concentrations. A similar pattern was found when the combined toxicity of the cyanotoxicant Microcystin (MC)-LR and $\mathrm{Cu}$ exposure was investigated in the aquatic plant Vallisneria natans, producing synergistic effects when combined at low concentrations (Wang et al., 2017). Considering this, it is worth to mention that CYN usually appears at low concentrations in nature (De la Cruz et al., 2013), making a synergistic toxic response very likely to appear.
To our knowledge, no studies concerning the effects of the combination of cyanotoxins and pesticides using neuronal cell lines have been carried out. However, in vivo, the first combination of cyanobacteria and pesticides was performed by Cerbin et al. (2010), using a strain of Microcystis aeruginosa and the carbamate carbaryl. In this study, the combination demonstrated a mostly additive interaction in Daphnia pulicaria after $24 \mathrm{~h}$ of exposure, while their effect in body deformations of newborns was even synergistic. Ondracek et al. (2012) exposed Japanese quails for 10 days to a combination of a cyanobacterial biomass with MCs (61.62 $\mu \mathrm{g}$ /day MCs), the OP paraoxon (2 doses of $250 \mu \mathrm{g} / \mathrm{kg}$ paraoxon in that period), and an anticoagulant (2 doses of $500 \mathrm{mg} / \mathrm{kg}$ bromadiolone). They observed that the combination induced more severe damages in the birds than the isolated compounds. This brings to light that the combination of cyanotoxins and pesticides usually drives to a synergistic response, which is in agreement with our results at low concentrations after $48 \mathrm{~h}$ of exposure. In contrast, Asselman et al. (2013) observed non-interactive and antagonistic effects for the 


\section{A}

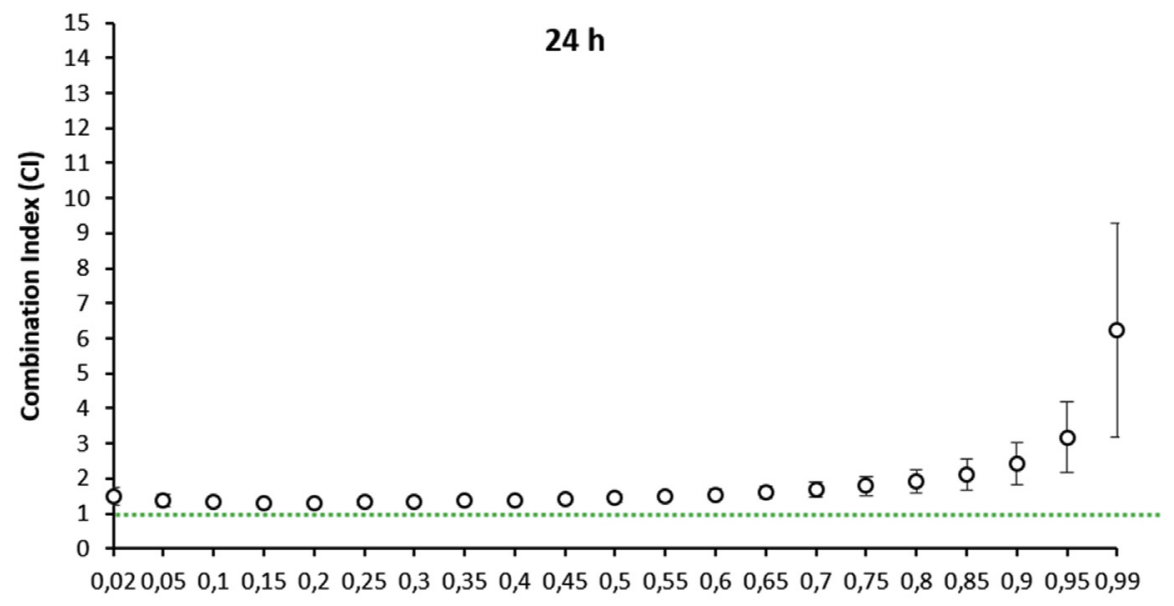

B

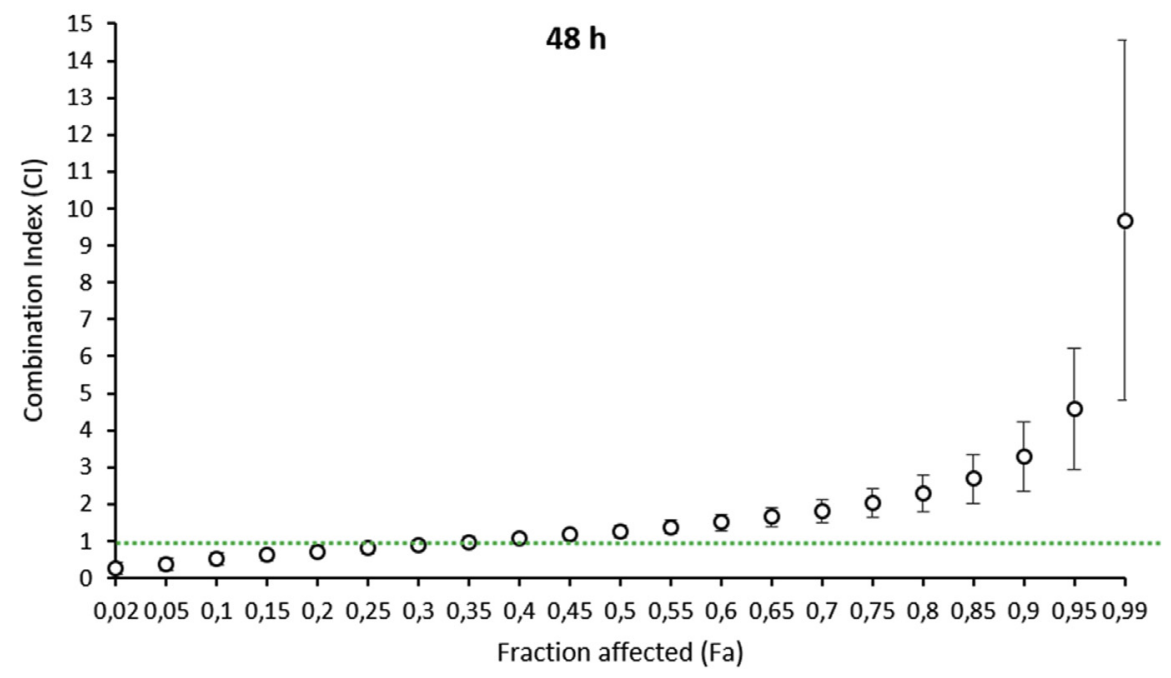

Fig. 3. Combination index (CI)/fraction affected (Fa) curve in SH-SY5Y cells exposed to CYN-CPF combination after $24 \mathrm{~h}$ (A) and $48 \mathrm{~h}$ (B) of exposure. Each point represents the $\mathrm{CI} \pm$ s.d. at a fractional effect. The dotted line $(\mathrm{CI}=1)$ indicates additivity, the area under the dotted line points out a synergist effect, and the area above the dotted line signifies antagonism.

A

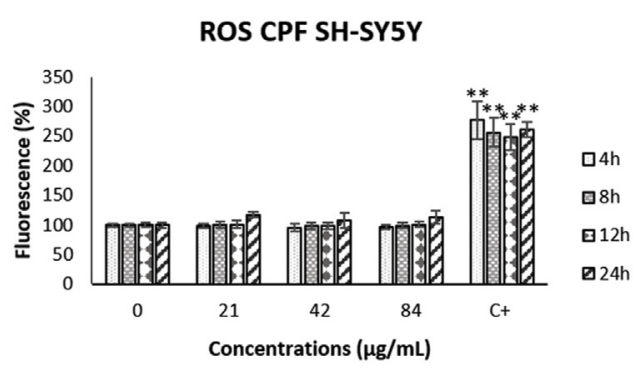

B

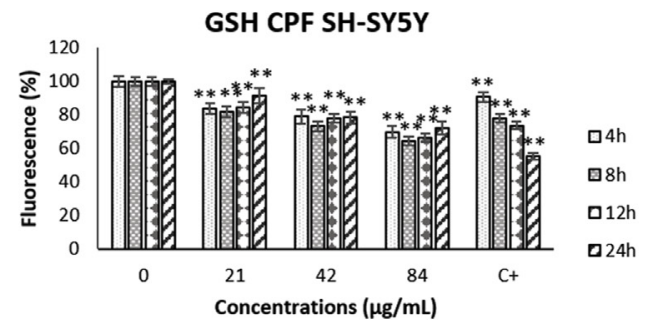

C

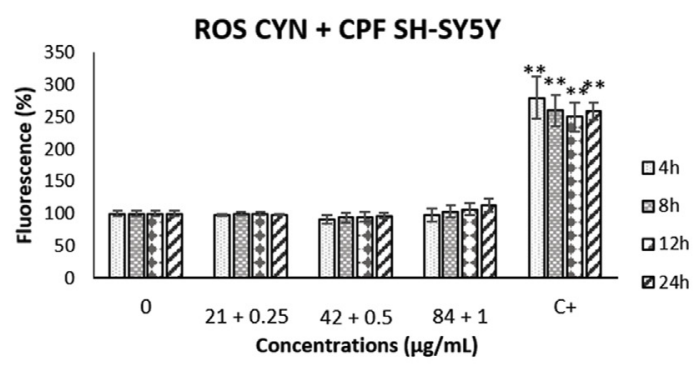

D

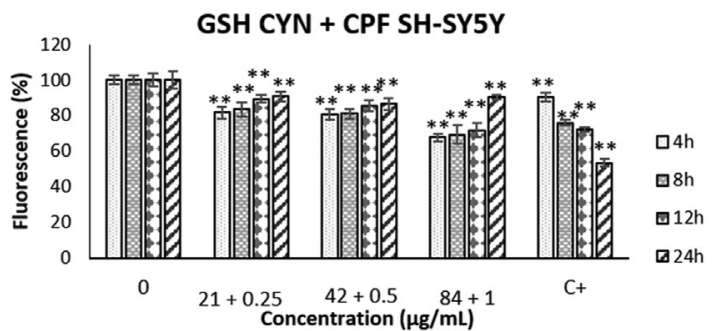

Fig. 4. Reactive oxygen species (ROS) levels on SH-SY5Y cells after 4, 8, 12 and $24 \mathrm{~h}$ of exposure to $0-84 \mu \mathrm{g} / \mathrm{mL}$ CPF (A) and a CYN-CPF combination at a ratio $1: 84$ of $\mathrm{EC}_{50} \mathrm{CYN}_{\mathrm{EC}} \mathrm{E}_{50} \mathrm{CPF}$ (C). Reduced glutathione (GSH) levels on SH-SY5Y cells after 4, 8, 12 and $24 \mathrm{~h}$ of exposure to $0-84 \mu \mathrm{g} / \mathrm{mL} \mathrm{CPF}$ (B) and a CYN-CPF combination at a ratio 1:84 of $\mathrm{EC}_{50} \mathrm{CYN} / \mathrm{EC}_{50} \mathrm{CPF}(\mathrm{D})$. All values are expressed as mean \pm s.d. The significance levels observed are **p $<0.01$ significantly different from control group. 


\section{AChE}

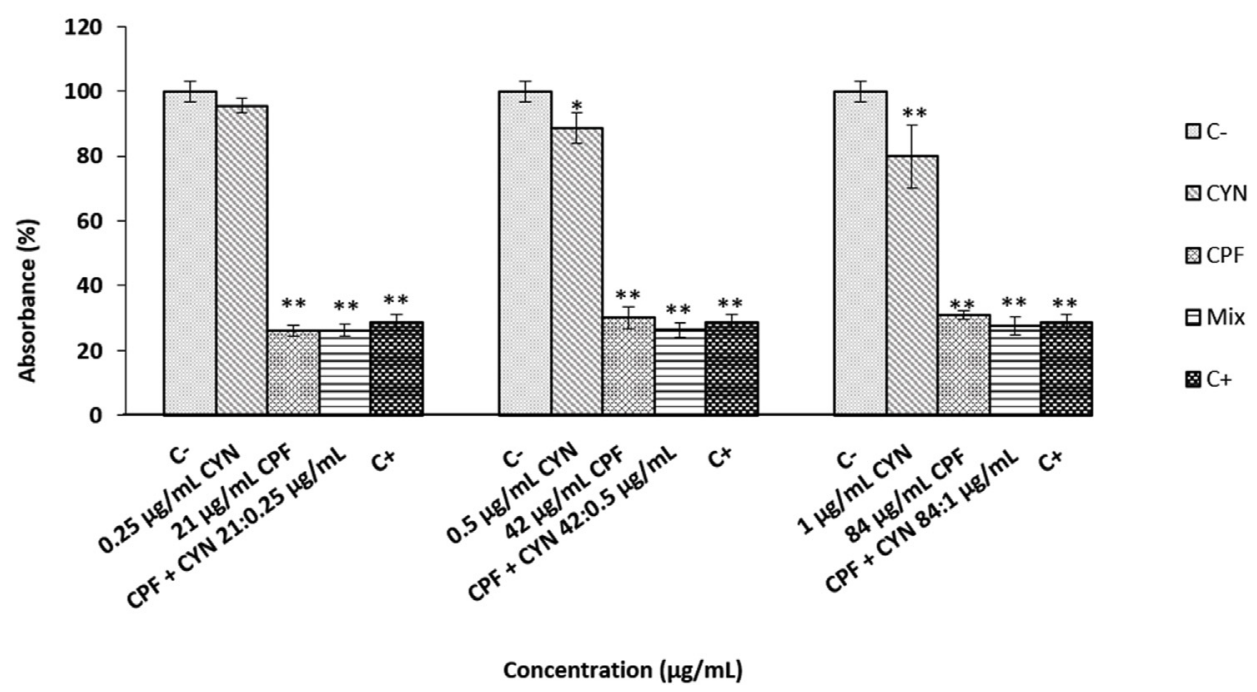

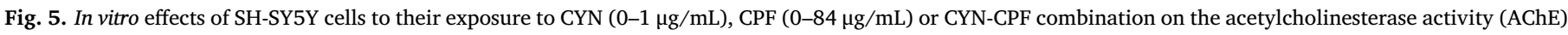
after $24 \mathrm{~h}$. All values are expressed as mean \pm s.d. ** Indicates significant difference from control group value (p $<0.01)$.

combination of carbaryl with four species of cyanobacteria (some of them CYN-producers) on Daphnia pulex. Moreover, when these same authors studied the effects of the combination of four different insecticides (including CPF) and M. aeruginosa on Daphnia pulex after 21 days of exposure, a different response was found (Asselman et al., 2014). They observed an additive response for CPF and the cyanobacterial strain, different from the antagonistic response they found using carbaryl, which presents the same mechanism of action (Asselman et al., 2013). For this reason, they postulated that interactive effects could not be generalized for compounds targeting the same pathway (Asselman et al., 2014).

Regarding the oxidative stress induction, the combination of CYN and CPF did not induce a significant variation in ROS levels compared to the control group, following the trend showed by CYN in Hinojosa et al. (2019) and CPF described in the present paper. Regarding the GSH levels, the combination of both compounds led to a reduction of its levels. However, the decline was lower than the one caused by CPF alone. This could be due to the fact that CYN alone did not induce any alteration on GSH levels in SH-SY5Y cells (Hinojosa et al., 2019). This decrease, as mentioned before, could be the consequence of a compensating mechanism for the oxidative stress, explaining the non-altered ROS levels shown by the mixture. Up to date, no more data concerning the oxidative stress induction of the combination of CYN and CPF in vitro is available. However, the oxidative stress induction of both toxicants has been assayed combined with other chemicals. The scientific literature is very scarce concerning to CYN. Our research group demonstrated that the combination of CYN with MC-LR did not induce an alteration of ROS levels but a slight reduction of GSH levels in SH-SY5Y cells (Hinojosa et al., 2019, Hinojosa et al., 2019). This is in agreement with the results presented in this paper, being worthy to point out that CYN ameliorates GSH levels in the mixture compared to $\mathrm{CPF}$ alone. Regarding CPF, its combination with other chemicals using $\mathrm{SH}$-SY5Y cells as in vitro model has resulted in different outcomes. Thus, Raszewski et al. (2015) found that the combination of CPF-cypermethrin, a synthetic pyrethroid, induced a synergistic response in the MTT assay, whereas a mixture of $\mathrm{CPF}$ and Cd presented an antagonistic response, not showing a deterioration of the oxidative stress status previously induced by $\mathrm{CPF}$ alone (Xu et al., 2017). These results support the theory that CYN could be the limiting factor of the combination.

Concerning the AChE status, the combination of CYN and CPF showed a similar pattern than CPF alone, thus is, an intense inhibition of the AChE activity. This same fact was described by Xu et al. (2017) in SH-SY5Y cells, who found that cadmium had no effect on the inhibitory AChE activity in combination with CPF. This result reveals, for the first time, that in a CYN-CPF mixture, $\mathrm{CPF}$ is the one that mainly determines the inhibition of the AChE enzyme.

Finally, regarding the morphological findings, Hinojosa et al. (2019) showed that CYN induced clear morphological alterations leading to cell death (apoptotic bodies, heterochromatin condensation, nuclei with an irregular shape, segregated nucleolus, and numerous mitochondria in the cytoplasm). These observations were very similar to those observed for CPF. Thus, the induction of mitochondrial dysfunction observed after CPF exposure could be explained not only by its intrinsic pro-oxidant capacity but also by altering mitochondrial architecture and dynamics (De Oliveira et al., 2016). The combination of CYN and CPF showed a more intense cell death by apoptosis than the individual exposure to CYN and CPF. This is in agreement with the results reported by Raszewski et al. (2015) and Xu et al. (2017) in SHSY5Y cells exposed to a combination of CPF and cypermethrin, and CPF and $\mathrm{Cd}$, respectively. In the last case, the observations at mitochondrial level were very similar to those described in the present paper, with swelling and fragmentation.

\section{Conclusions}

Our findings indicate that the combination of CYN and CPF induces GSH depletion, AChE activity inhibition, and cell death by apoptosis in the human neuroblastoma SH-SY5Y cell line. In comparison to CYN and $\mathrm{CPF}$ alone, an intensification of these effects was observed in this cell line after exposure to the mixture. However, these observations were less severe than expected, which was corroborated by the isobologram method. Thus, a mainly antagonistic response was established between both compounds. Nevertheless, a synergistic effect between both substances was observed at low concentrations after $48 \mathrm{~h}$, which requires special attention in order to not underestimate the exposure concentrations. Hence, from a toxicological point of view, it is important to consider the exposure pattern (single or mixtures) as results can differ. Further research is required to contribute to the risk assessment of CYN and other contaminants considering more realistic exposure scenarios. 

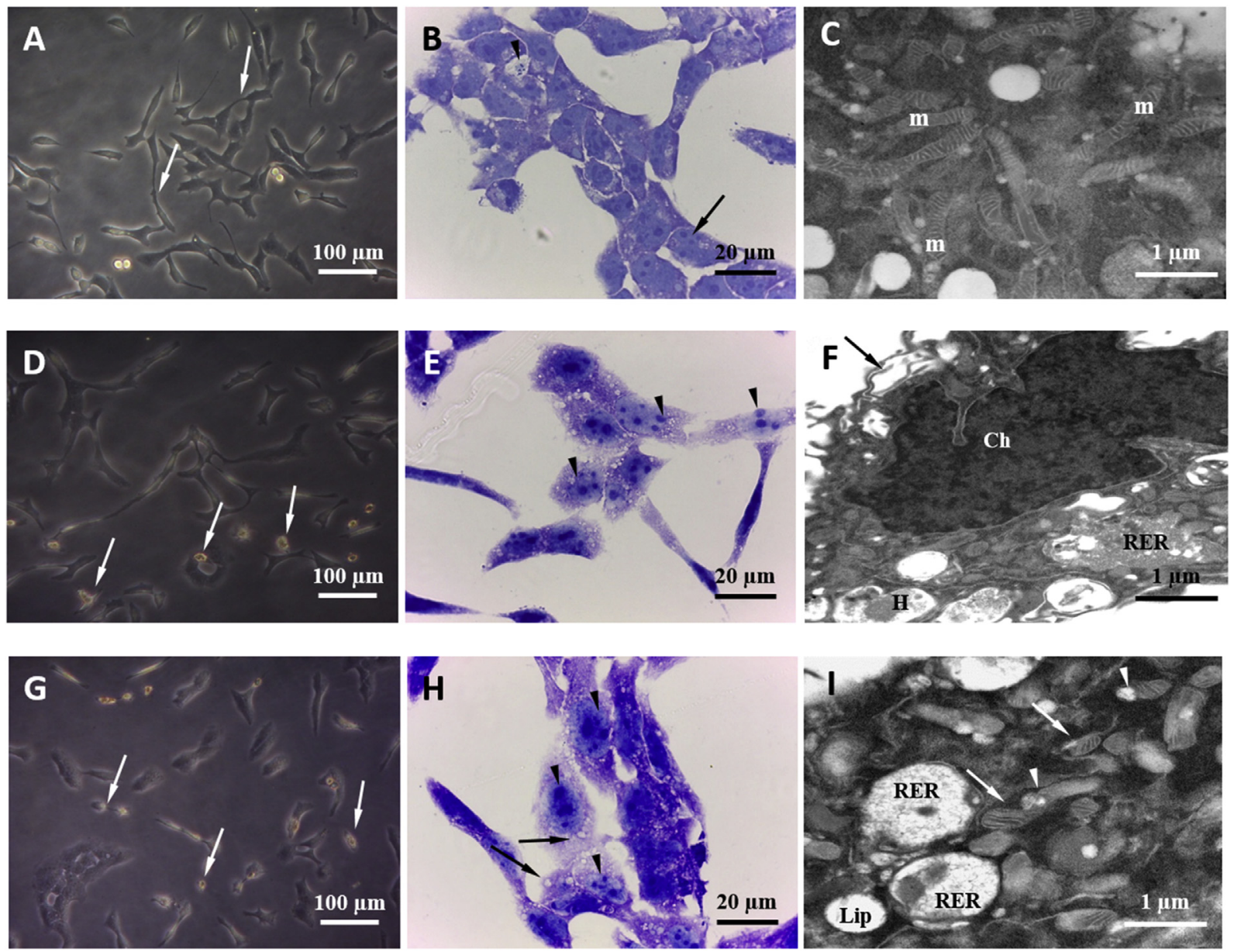

Fig. 6. Morphology of control SH-SY5Y cells after $24 \mathrm{~h}$ of exposure to culture medium without serum. Contrast-phase microscopy of a SH-SY5Y cell culture in normal neuronal growth. Cells present cytoplasmic projections contacting with other cells (arrows) Bar $=100 \mu \mathrm{m}(\mathrm{A})$. Semithin sections of cells culture were stained with toluidine blue. Cells in mitosis processes (arrowheads) with big nucleoli in the nucleus (arrows). Bar $=20 \mu \mathrm{m}$ (B). Transmission electronic microscopy of SH-SY5Y cells with numerous mitochondria (m). Bar $=1 \mu \mathrm{m}(\mathrm{C})$. Morphology of SH-SY5Y cells after $24 \mathrm{~h}$ of exposure to CPF. Phase-contrast microscopy of cells exposed to $42.5 \mu \mathrm{g} / \mathrm{mL}$ CPF presented rounded cells (arrows) with clear signs of cell death. Bar $=100 \mu \mathrm{m}$ (D). Semithin sections of cells exposed to $85 \mu \mathrm{g} / \mathrm{mL} \mathrm{CPF}$ presented nuclei with condensed chromatin (arrowheads) as clear sign of cell death. Bar $=20 \mu \mathrm{m}$ (E). Electronic microscopy of cells exposed to $85 \mu \mathrm{g} / \mathrm{mL} \mathrm{CPF}$ showed irregular nuclei with chromatin condensation (Ch), appearance of blisters in the cellular membrane (arrows), dilated RER with protein content (RER) and presence of heterophagosomes $(\mathrm{H})$. Bar $=1 \mu \mathrm{m}(\mathbf{F})$. Phase-contrast microscopy of SH-SY5Y cells exposed to the combination of CYN and CPF showed cell death signs at all the concentrations assayed. Bar $=100 \mu \mathrm{m}$ (G). Semithin sections of cells culture exposed to $0.5+42 \mu \mathrm{g} / \mathrm{mL}$ CYN + CPF presented lipid droplets (arrows) and big nucleoli (arrowheads). Bar $=20 \mu \mathrm{m}(\mathrm{H})$. The TEM of cells exposed to the highest concentration of the combination showed altered dilated mitochondria (arrows) surrounded by lipidic droplets (arrowheads). The endoplasmic reticulum cisternae appeared dilated (RER) and lipidic vacuoles were formed (Lip). Bar $=1 \mu \mathrm{m}$ (I). (For interpretation of the references to colour in this figure legend, the reader is referred to the Web version of this article.)

\section{CRediT authorship contribution statement}

M.G. Hinojosa: Conceptualization, Methodology, Formal analysis, Investigation, Writing - original draft, Writing - review \& editing, Visualization. A.I. Prieto: Conceptualization, Validation, Writing - review \& editing, Supervision. D. Gutiérrez-Praena: Conceptualization, Methodology, Validation, Formal analysis, Writing - original draft, Writing - review \& editing, Visualization, Supervision. F.J. Moreno: Validation, Investigation. A.M. Cameán: Conceptualization, Validation, Writing - review \& editing, Supervision, Project administration, Funding acquisition. A. Jos: Conceptualization, Validation, Writing - review \& editing, Supervision, Project administration, Funding acquisition.

\section{Acknowledgements}

The authors wish to thank the Ministerio de Economía y Competitividad of Spain (AGL 2015-64558-R, MINECO/FEDER, UE) for the financial support, the Junta de Andalucía for the contact of María
Gracia Hinojosa (USE-16667), and the Biology Service and Microscopy Service of Centro de Investigación, Tecnología e Innovación from Universidad de Sevilla (CITIUS), for providing technical assistance.

\section{References}

Al-Badrany, Y.M.A., Mohammad, F.K., 2007. Effects of acute and repeated oral exposure to the organophosphate insecticide chlorpyrifos on open-field activity in chicks. Toxicol. Lett. 174, 110-116. https://doi.org/10.1016/j.toxlet.2007.09.001.

Al-Sammak, M.A., Hoagland, K.D., Cassada, D., Snow, D.D., 2014. Co-occurrence of the cyanotoxins BMAA, DABA and anatoxin-a in Nebraska reservoirs, fish, and aquatic plants. Toxins 6, 488-508. https://doi.org/10.3390/toxins6020488.

Amani, N., Soodi, M., Daraei, B., Dashti, A., 2016. Chlorpyrifos toxicity in mouse cultured cerebellar granule neurons at different stages of development: additive effect on glutamate-induced excitotoxicity. Cell J 18, 464-472. https://doi.org/10.22074/ cellj.2016.4575.

Antunes, J.T., Leão, P.N., Vasconcelos, V.M., 2015. Cylindrospermopsis raciborskii: review of the distribution, phylogeography, and ecophysiology of a global invasive species. Front. Microbiol. 6, 1-13. https://doi.org/10.3389/fmicb.2015.00473.

Asselman, J., Meys, J., Waegeman, W., de Baets, B., de Schamphelaere, K.A.C., 2013. Combined exposure to cyanobacteria and carbaryl results in antagonistic effects on the reproduction of Daphnia pulex. Eviron. Toxicol. Chem. 32, 2153-2158. https:// doi.org/10.1002/etc.2296. 
Asselman, J., Janssen, C.R., Smagghe, G., De Schamphelaere, K.A.C., 2014. Ecotoxicity of binary mixtures of Microcystis aeruginosa and insecticides to Daphnia pulex. Environ. Pollut. 188, 56-63. https://doi.org/10.1016/j.envpol.2014.01.018.

Bourke, A.T.C., Hawes, R.B., Neilson, A., Stallman, N.D., 1983. An outbreak of hepatoenteritis (the Palm Island mystery disease) possibly caused by algal intoxication. Toxicon 21, 45-48. https://doi.org/10.1016/0041-0101(83)90151-4.

Brooks, B.W., Lazorchak, J.M., Howard, M.D.A., Johnson, M.V.V., Morton, S.L., Perkins, D.A.K., Reavie, E.D., Scott, G.I., Smith, S.A., Steevens, J.A., 2017. In some places, in some cases and at some times, harmful algal blooms are the greatest threat to inland water quality. Environ. Toxicol. Chem. 36, 1125-1127. https://doi.org/10.1002/etc. 3801.

Buratti, F.M., Manganelli, M., Vichi, S., Stefanelli, M., Scardala, S., Testai, E., Funari, E., 2017. Cyanotoxins: producing organisms, occurrence, toxicity, mechanism of action and human health toxicological risks evaluation. Arch. Toxicol. 91, 1049-1130. https://doi.org/10.1007/s00204-016-1913-6.

Carvalho, C., 2012. Joint Toxicity Effects of Cyanotoxins and Chemical Compounds. Universidade de Aveiro.

Cerbin, S., Kraak, M.H.S., de Voogt, P., Visser, P.M., Van Donk, E., 2010. Combined and single effects of pesticide carbaryl and toxic Microcystis aeruginosa on the life history of Daphnia pulicaria. Hydrobiologia 643, 129-138. https://doi.org/10.1007/s10750010-0130-1.

Chen, W., Jia, Y., Liu, A., Zhou, Q., Song, L., 2017. Simultaneous elimination of cyanotoxins and PCBs via mechanical collection of cyanobacterial blooms: an application of "green-bioadsorption concept". J. Environ. Sci. 57, 118-126. https://doi.org/10. 1016/j.jes.2016.11.011.

Cook, W.O., Beasley, V.R., Dahlem, A.M., Dellinger, J.A., Harlin, K.S., Carmichael, W.W., 1988. Comparison of effects of anatoxin-a(s) and paraoxon, physostigmine and pyridostigmine on mouse brain cholinesterase activity. Toxicon 26, 750-753. https:// doi.org/10.1016/0041-0101(88)90282-6.

Cordeiro-Araújo, M.K., Chia, M.A., Bittencourt-Oliveira, M.C., 2017. Potential human health risk assessment of cylindrospermopsin accumulation and depuration in lettuce and arugula. Harmful Algae 68, 217-223. https://doi.org/10.1016/j.hal.2017.08. 010.

Daam, M.A., Cerejeira, M.J., Van den Brink, P.J., Brock, T.C.M., 2011. Is it possible to extrapolate results of aquatic microcosm and mesocosm experiments with pesticides between climate zones in Europe? Environ. Sci. Pollut. Res. 18, 123-126. https://doi. org/10.1007/s11356-010-0406-z.

Da Silva, R.C., Grötzner, S.R., Moura Costa, D.D., Garcia, J.R.E., Muelbert, J., de Magalhães, V.F., Neto, F.F., Ribeiro, A.O., 2018. Comparative bioaccumulation and effects of purified and cellular extract of cylindrospermopsin to freshwater fish Hoplias malabaricus. J. Toxicol. Environ. Health Part A Curr Issues. 81, 620-632. https://doi.org/10.1080/15287394.2018.1469101.

De la Cruz, A.A., Hiskia, A., Kaloudis, T., Chernoff, N., Hill, D., Antoniou, M.G., He, X. Loftin, K., O'Shea, K., Zhao, C., Pelaez, M., Han, C., Lynch, T.J., Dionysiou, D.D., 2013. A review on cylindrospermopsin: the global occurrence, detection, toxicity and degradation of a potent cyanotoxin. Environ. Sci. Process Impacts 15, 1979-2003. https://doi.org/10.1039/c3em00353a.

De Oliveira, M.R., Peres, A., Ferreira, G.C., Schuck, P.F., Dal Bosco, S.M., 2016. Carnosic acid affords mitocondrial protection in chlorpyrifos-treated SH-SY5Y cells. Neurotox. Res. 30, 367-379. https://doi.org/10.1007/s12640-016-9620-x.

Eaton, D.L., Daroff, R.B., Autrup, H., Bridges, J., Buffler, P., Costa, L.G., Coyle, J., McKhann, G., Mobley, W.C., Nadel, L., Neubert, D., Schulte-Hermann, R., Spencer P.S., 2008. Review of the toxicology of chlorpyrifos with an emphasis on human exposure and neurodevelopment. Crit. Rev. Toxicol. 2, 1-125. https://doi.org/10. 1080/10408440802272158.

Ellman, G.L., Courtney, K.D., Andres, V., Featherstone, R.M., 1961. A new and rapid colorimetric determination of acetylcholinesterase activity. Biochem. Pharmacol. 7 88-95. https://doi.org/10.1016/0006-2952(61)90145-9.

Falconer, I.R., 1999. An overview of problems caused by toxic blue-green algae (cyanobacteria) in drinking and recreational water. Environ. Toxicol. 14, 5-12. https://doi org/10.1002/(SICI)1522-7278(199902)14:1 < 5::AID-TOX3 > 3.0.CO;2-0.

Froscio, S.M., Humpage, A.R., Burcham, P.C., Falconer, I.R., 2003. Cylindrospermopsininduced protein synthesis inhibition and its dissociation from acute toxicity in mouse hepatocytes. Environ. Toxicol. 18, 243-251. https://doi.org/10.1002/tox.10121.

Fu, D.J., Li, P., Song, J., Zhang, S.Y., Xie, H.Z., 2019. Mechanisms of synergistic neurotoxicity induced by two high risk pesticide residues - chlorpyrifos and Carbofuran via oxidative stress. Toxicol. In Vitro 54, 338-344. https://doi.org/10.1016/j.tiv.2018. 10.016.

Giordano, G., Afsharinejad, Z., Guizzetti, M., Vitalone, A., Kavanagh, T.J., 2007. Costa Organophosphorus insecticides chlorpyrifos and diazinon and oxidative stress in neuronal cells in a genetic model of glutathione deficiency. Toxicol. Appl. Pharmacol. 219, 181-189. https://doi.org/10.1016/j.taap.2006.09.016.

Griffiths, D.J., Saker, M.L., 2003. The Palm Island mystery disease 20 years on: a review of research on the cyanotoxin cylindrospermopsin. Environ. Toxicol. 18, 78-93. https://doi.org/10.1002/tox.10103.

Gutiérrez-Praena, D., Jos, A., Pichardo, S., Moreno, I.M., Cameán, A.M., 2013. Presence and bioaccumulation of microcystins and cylindrospermopsin in food and the effectiveness of some cooking techniques at decreasing their concentrations: a review. Food Chem. Toxicol. 53, 139-152. https://doi.org/10.1016/j.fct.2012.10.062.

Guzmán-Guillén, R., Prieto, A.I., Vasconcelos, V.M., Cameán, A.M., 2013. Cyanobacterium producing cylindrospermopsin cause oxidative stress at environmentally relevant concentrations in sub-chronically exposed tilapia (Oreochromis nicoticus). Chemosphere 90, 1184-1194. https://doi.org/10.1016/j. chemosphere.2012.09.027.

Guzmán-Guillén, R., Manzano, I.L., Moreno, I.M., Prieto, A.I., Moyano, R., Blanco, A., Cameán, A.M., 2015. Cylindrospermopsin induces neurotoxicity in tilapia fish
(Oreochromis nicotilus) exposed to Aphanizomenon ovalisporum. Aquat. Toxicol. 161, 17-24. https://doi.org/10.1016/j.aquatox.2015.01.024.

Hawkins, P.R., Runnegar, M.T., Jackson, A.R., Falconer, I.R., 1985. Severe hepatotoxicity caused by the tropical cyanobacterium (blue-green alga) Cylindrospermopsis raciborskii (Woloszynska) Seenaya and Subba Raju isolated from a domestic water supply reservoir. Appl. Environ. Microbiol. 50, 1292-1295 0099-2240/85/11129204\$02.00/O.

Hinojosa, M.G., Gutiérrez-Praena, D., Prieto, A.I., Guzmán-Guillén, R., Jos, A., Cameán, A.M., 2019. Neurotoxicity induced by microcystins and cylindrospermopsin: a review. Sci. Total Environ. 668, 547-565. https://doi.org/10.1016/j.scitotenv.2019. 02.426 .

Hinojosa, M.G., Prieto, A.I., Gutiérrez-Praena, D., Moreno, F.J., Cameán, A.M., Jos, A., 2019. Neurotoxic assessment of microcystin-LR, cylindrospermopsin and their combination on the human neuroblastoma SH-SY5Y cell line. Chemosphere 224, 751-764. https://doi.org/10.1016/j.chemosphere.2019.02.173.

Holmstrup, M., Bindesbøl, A.M., Oostingh, G.J., Duschi, A., Scheil, V., Köhler, H.R., Loureiro, S., Soares, A.M.V.M., Ferreira, A.L.G., Kienle, C., Gerhardt, A., Laskowski, R., Kramarz, P.E., Bayley, M., Svendsen, C., Spurgeon, D.J., 2010. Interactions between effects of environmental chemicals and natural stressors: a review. Sci. Total Environ. 408, 3746-3762. https://doi.org/10.1016/j.scitotenv.2009.10.067.

Humpage, A.R., Fontaine, F., Froscio, S., Burcham, P., Falconer, I.R., 2005. Cylindrospermopsin genotoxicity and cytotoxicity: role of cytochrome P-450 and oxidative stress. J. Toxicol. Environ. Health Part A 68, 739-753. https://doi.org/10. 1080/15287390590925465.

Koly, F.A., Khan, R.A., 2018. Biodegradation of organophosphorous pesticide: chlorpyrifos. ARPG 5, 8-18. https://doi.org/10.32861/sr.51.8.18.

Laskowski, R., Bednarska, A.J., Kramarz, P.E., Loureiro, S., Scheil, V., Kudłek, J., Holmstrup, M., 2010. Interactions between toxic chemicals and natural environmental factors- A meta-analysis and case studies. Sci. Total Environ. 408, 3763-3774. https://doi.org/10.1016/j.scitotenv.2010.01.043.

Machado, J., Campos, A., Vasconcelos, V., Freitas, M., 2017. Effects of microcystin-LR and cylindrospermopsin on plant-soil systems: a review of their relevance from agricultural plan quality and public health. Environ. Res. 153, 191-204. https://doi.org/ 10.1016/j.envres.2016.09.015.

Maisanaba, S., Guzmán-Guillén, R., Puerto, M., Gutiérrez-Praena, D., Ortuño, N., Jos, A., 2018. In vitro toxicity evaluation of new silane-modified clays and the migration extract from a derived polymer-clay nanocomposite intended to food packaging applications. J. Hazard Mater. 341, 313-320. https://doi.org/10.1016/j.jhazmat.2017. 08.003.

Manning, S.R., Nobles, D.R., 2017. Impact of global warming on water toxicity: cyanotoxins. Curr. Opin. Food Sci. 18, 14-20. https://doi.org/10.1016/j.cofs. 2017.09.013.

Martinez-Ruiz, E.B., Martínez-Jerónimo, F., 2016. How do toxic metals affect harmful cyanobacteria? An integrative study with a toxigenic strain of Microcystis aeruginosa exposed to nickel stress. Ecotoxicol. Environ. Saf. 133, 36-46. https://doi.org/10. 1016/j.ecoenv.2016.06.040.

Medrano-Padial, C., Puerto, M., Moreno, F.J., Richard, T., Cantos-Villar, E., Pichardo, S., 2019. In vitro toxicity assessment of stilbene extract for its potential use as antioxidant in the wine industry. Antioxidants 8, 1-16. https://doi.org/10.3390/ antiox8100467.

Mehta, A., Verma, R.S., Srivastava, N., 2009. Chlorpyrifos induced alterations in the levels of hydrogen peroxide, nitrate and nitrite in rat brain and liver. Pestic. Biochem. Physiol. 94, 55-59. https://doi.org/10.1016/j.pestbp.2009.04.001.

Moe, S.J., De Schamphelaere, K.A.C., Clements, W.H., Sorensen, M.T., Van den Brink, P.J., Liess, M., 2012. Combined and interactive effects of global climate change and toxicants on populations and communities. Environ. Toxicol. Chem. 32, 49-61. https://doi.org/10.1002/etc.2045. 2012.

Ohtani, I., Moore, R.E., Runnegar, M.T.C., 1992. Cylindrospermopsin: a potent hepatotoxin from the blue-green alga Cylindrospermopsis raciborskii. J. Am. Chem. Soc. 114, 7941-7942. https://doi.org/10.1021/ja00046a067.

Ondracek, K., Bandouchova, H., Damkova, V., Hilscherova, K., Kral, J., Osickova, J., Mlcakova, V., Pohanka, M., Skochova, H., Vitula, F., Treml, F., Pikula, J., 2012. Risk of combined exposure of birds to cyanobacterial biomass containing microcystins, acetylcholinesterase inhibitor and anticoagulant. Neuroendocrinol. Lett. 33, $155-160$.

Park, J.H., Lee, J.E., Shin, I.C., Koh, H.C., 2013. Autophagy regulates chlorpyrifos-induced apoptosis in SH-SY5Y cells. Toxicol. Appl. Pharmacol. 268, 55-67. https://doi. org/10.1016/j.taap.2013.01.013.

Park, J.H., Ko, J., Hwang, J., Koh, H.C., 2015. Dynamin-related protein 1 mediates mitochondria-dependent apoptosis in chlorpyrifos-treated SH-SY5Y cells. Neurotoxicology (Little Rock) 51, 145-157. https://doi.org/10.1016/j.neuro.2015 10.008.

Pathmalal, M.M., 2019. Cyanotoxins: a hidden cause of chronic kidney disease of unknown etiology (CKDu) in Sri Lanka - a review. J. Aquat. Sci. 24, 1-10. https://doi. org/10.4038/sljas.v24i1.7562.

Puerto, M., Campos, A., Prieto, A., Cameán, A., de Almeida, A.M., Coelho, A.V., Vasconcelos, V., 2011. Differential protein expression in two bivalve species; Mytilus galloprovincialis and Corbicula fluminea; exposed to Cylindrospermopsis raciborskii cells. Aquat. Toxicol. 101, 109-116. https://doi.org/10.1016/j.aquatox.2010.09.009.

Puerto, M., Prieto, A.I., Maisanaba, S., Gutiérrez-Praena, D., Mellado-García, P., Jos, A., Cameán, A.M., 2018. Mutagenic and genotoxic potential of pure cylindrospermopsin by a battery of in vitro tests. Food Chem. Toxicol. 121, 413-422. https://doi.org/10. 1016/j.fct.2018.09.013.

Raszewski, G., Lemieszek, M.K., Łukawski, K., Juszczak, M., Rzeski, W., 2015. Chlorpyrifos and cypermethrin induce apoptosis in human neuroblastoma cell line SH-SY5Y. Basic Clin. Pharmacol. Toxicol. 116, 158-167. https://doi.org/10.1111/ bcpt.12285. 
Santillo, M.F., Liu, Y., 2015. A fluorescence assay for measuring acetylcholinesterase activity in rat blood and a human neuroblastoma cell line (SH-SY5Y). J. Pharmacol. Toxicol. Methods 76, 15-22. https://doi.org/10.1016/j.vascn.2015.07.002.

Takser, L., Benachour, N., Husk, B., Cabana, H., Gris, D., 2016. Cyanotoxins at low doses induce apoptosis and inflammatory effects in murine brain cells: potential implications for neurodegenerative diseases. Toxicol. Rep. 3, 180-189. https://doi.org/10. 1016/j.toxrep.2015.12.008.

Tatay, E., Meca, G., Font, G., Ruiz, M.J., 2014. Interactive effects of zearalenone and its metabolites on cytotoxicity and metabolization in ovarian CHO-K1 cells. Toxicol. In Vitro 28, 95-103. https://doi.org/10.1016/j.tiv.2013.06.025.

Tatters, A.O., Howard, M.D.A., Nagoda, C., Busse, L., Gellene, A.G., Caron, D.A., 2017. Multiple stressors at the land-sea interface: cyanotoxins at the land-sea interface in the southern california bight. Toxins 95, 1-17. https://doi.org/10.3390/ toxins 9030095 .

Terao, K., Ohmori, S., Igarashi, K., Ohtani, I., Watanabe, M.F., Harada, K.I., Ito, E., Watanabe, M., 1994. Electron microscopic studies on experimental poisoning in mice induced by cylindrospermopsin isolated from blue-green alga Umezakia natans. Toxicon 32, 833-843. https://doi.org/10.1016/0041-0101(94)90008-6.

Testai, E., Buratti, F.M., Funari, E., Manganelli, M., Vichi, S., Arnich, N., Biré, R., Fessard,
V., Sialehaamoa, A., 2016. Review and analysis of occurrence, exposure and toxicity of cyanobacteria toxins in food. EFSA Support. Publ. 13, 1-309. https://doi.org/10. 2903/sp.efsa.2016.EN-998.

Uchendu, C., Ambali, S.F., Ayo, J.O., 2012. The organophosphate, chlorpyrifos, oxidative stress and the role of some antioxidants: a review. Afr. J. Agric. 7, 2720-2728. https://doi.org/10.5897/AJAR11.2510.

Wang, Z., Zhang, J., Li, E., Zhang, L., Wang, X., Song, L., 2017. Combined toxic effects and mechanisms of microsystin-LR and copperon Vallisneria Natans (Lour.) Hara seedlings. J. Hazard Mater. 328, 108-116. https://doi.org/10.1016/j.jhazmat.2016.12. 059.

Xu, M.Y., Wang, P., Sun, Y.J., Yang, L., Wu, Y.J., 2017. Joint toxicity of chlorpyrifos and cadmium on the oxidative stress and mitochondrial damage in neuronal cells. Food Chem. Toxicol. 103, 246-252. https://doi.org/10.1016/j.fct.2017.03.013.

Žegura, B., Štraser, A., Filipič, M., 2011. Genotoxicity and potential carcinogenicity of cyanobacterial toxins - a review. Rev. Mutat. Res. Rev. Mutat. Res. 727, 16-41. https://doi.org/10.1016/j.mrrev.2011.01.002.

Zheng, Q., Olivier, K., Won, Y.K., Pope, C.N., 2000. Comparative cholinergic neurotoxicity of oral chlorpyrifos exposures in preweanling and adult rats. Toxicol. Sci. 55, 124-132. https://doi.org/10.1093/toxsci/55.1.124. 